\title{
Plasma-induced, nitrogen-doped graphene-based aerogels for high-performance supercapacitors
}

\author{
Xue-Yu Zhang ${ }^{1}$, Shi-Han Sun ${ }^{1}$, Xiao-Juan Sun ${ }^{2}$, Yan-Rong Zhao ${ }^{1}$, Li Chen ${ }^{3}$, Yue Yang ${ }^{1}$, Wei Lü ${ }^{1}$ and \\ Da-Bing $\mathrm{Li}^{2}$
}

Commonly used energy storage devices include stacked layers of active materials on two-dimensional sheets, and the limited specific surface area restricts the further development of energy storage. Three-dimensional (3D) structures with high specific surface areas would improve device performance. Herein, we present a novel procedure to fabricate macroscopic, high-quality, nitrogen-doped, 3D graphene/nanoparticle aerogels. The procedure includes vacuum filtration, freeze-drying, and plasma treatment, which can be further expanded for large-scale production of nitrogen-doped, graphene-based aerogels. The behavior of the supercapacitor is investigated using a typical nitrogen-doped graphene/ $\mathrm{Fe}_{3} \mathrm{O}_{4}$ nanoparticle $3 \mathrm{D}$ structure $\left(\mathrm{NG} / \mathrm{Fe}_{3} \mathrm{O}_{4}\right)$. Compared with $3 \mathrm{D}$ graphene/ $/ \mathrm{Fe}_{3} \mathrm{O}_{4}$ structures prepared by the traditional hydrothermal method, the $\mathrm{NG} / \mathrm{Fe}_{3} \mathrm{O}_{4}$ supercapacitor prepared by the present method has a $153 \%$ improvement in specific capacitance, and there is no obvious decrease in specific capacitance after 1000 cycles. The present work provides a new and facile method to produce large-scale, 3D, graphene-based materials with high specific capacitance for energy storage.

Light: Science \& Applications (2016) 5, e16130; doi:10.1038//sa.2016.130; published online 7 October 2016

Keywords: energy storage; N-doping; plasma; three-dimension

\section{INTRODUCTION}

The intrinsic two-dimensional (2D) structure of graphene provides unique physical properties, making it possible to fabricate selfassembled, three-dimensional (3D) architectures ${ }^{1-13}$. Combining functional nanomaterials with 3D graphene structures would enhance their specific applications. Recently, 3D, graphene-based materials have attracted attention due to their porous structure, which provides a high specific surface area and synergistic effects in the composites $^{14-19}$. The 3D, graphene-based hybrids are becoming candidates for energy storage, such as in $\mathrm{Li}$ ion batteries, hydrogen storage and supercapacitors ${ }^{20-24}$. Several methods have been reported for fabricating 3D, porous, graphene-based structures, including chemical vapor deposition ${ }^{25}$, growth assisted by a template ${ }^{26-28}$ and chemical self-assembly ${ }^{29-34}$. In spite of the significant development for constructing 3D graphene-based structures, these commonly used fabrication methods are generally multistep, hard to control and involve harmful chemical agents. Therefore, further development for preparing high-quality 3D structures is still highly desirable.

In addition, the capacitance of intrinsic graphene is not sufficient for commercial applications but can be improved by N-doping ${ }^{35-39}$. The preparation of $\mathrm{N}$-doped graphene sheets by arc discharge/plasma treatment and chemical vapor deposition (CVD) thermal annealing of graphene oxide $(\mathrm{GO})$ with $\mathrm{NH}_{3}$ have been reported ${ }^{35,40,41}$. Plasma treatment is an eco-friendly and efficient way to produce $\mathrm{N}$-doped graphene sheets, and several reports have demonstrated N-doping of graphene by plasma ${ }^{42,43}$. However, these reports address $2 \mathrm{D}$ structures and are not aimed at energy storage. A method for fabricating highquality, N-doped, graphene-based, hybrid, 3D structures does not exist.

In this work, we report a novel method for preparing $\mathrm{N}$-doped, 3D, graphene/ $\mathrm{Fe}_{3} \mathrm{O}_{4}$, nanoparticle aerogel $\left(\mathrm{NG} / \mathrm{Fe}_{3} \mathrm{O}_{4}\right)$, which can be expanded for large-scale production of nitrogen-doped, graphenebased aerogel and various active nanomaterials can be incorporated into the 3D hybrid structures. The high-quality $\mathrm{NG} / \mathrm{Fe}_{3} \mathrm{O}_{4}$ aerogels are acquired by controllable physical treatment of GO. Compared with the $3 \mathrm{D}$ reduced-graphene $/ \mathrm{Fe}_{3} \mathrm{O}_{4}\left(\mathrm{RGO} / \mathrm{Fe}_{3} \mathrm{O}_{4}\right)$ prepared by the commonly used hydrothermal method, the present method produces greatly improved porous networks and exhibits significantly enhanced supercapacitor performance. The present work provides a new and facile method to produce high-quality, 3D, graphene-based materials for application in energy storage.

\section{MATERIALS AND METHODS}

Preparation of $\mathrm{GO}$ and $\mathrm{Fe}_{3} \mathrm{O}_{4}$ nanoparticles

A modified Hummers method was used to prepare GO. $\mathrm{Fe}_{3} \mathrm{O}_{4}$ nanoparticles (NPs) were prepared by $\mathrm{FeCl}_{3} \cdot 6 \mathrm{H}_{2} \mathrm{O}(58 \mathrm{mg})$ and $\mathrm{FeCl}_{2} \cdot 4 \mathrm{H}_{2} \mathrm{O}$ (21.5 mg), which were added to $30 \mathrm{ml}$ deionized water and deoxygenated for $15 \mathrm{~min}$ with nitrogen gas. After heating

\footnotetext{
${ }^{1}$ Key Laboratory of Advanced Structural Materials, Ministry of Education \& Advanced Institute of Materials Science, Changchun University of Technology, Changchun 130012, China; ${ }^{2}$ State Key Laboratory of Luminescence and Applications, Changchun Institute of Optics, Fine Mechanics and Physics, Chinese Academy of Sciences, Changchun 130033 , China and ${ }^{3}$ School of Basic Sciences \& Advanced Institute of Materials Science, Changchun University of Technology, Changchun 130012, China

Correspondence: DB Li, Email: lidb@ciomp.ac.cn; W Lü, Email: Iw771119@hotmail.com

Received 26 January 2016; revised 6 March 2016; accepted 7 March 2016; accepted article preview online 8 March 2016
} 
to $80{ }^{\circ} \mathrm{C}, \mathrm{N}_{2} \mathrm{H}_{4} \cdot \mathrm{H}_{2} \mathrm{O}(600 \mu \mathrm{l}, 20 \mathrm{wt} \%)$ was injected rapidly and kept stirring for $1 \mathrm{~h}$. The resulting $\mathrm{Fe}_{3} \mathrm{O}_{4} \mathrm{NPs}$ were separated from the reaction mixture with a magnet after cooling to room temperature.

\section{Preparation of $\mathrm{NG} / \mathrm{Fe}_{3} \mathrm{O}_{4}$}

A GO solution, including appropriate $\mathrm{Fe}_{3} \mathrm{O}_{4} \mathrm{NPs}$, was stirred for $1 \mathrm{~h}$ to obtain the $\mathrm{GO} / \mathrm{Fe}_{3} \mathrm{O}_{4}$ suspension. Then, the $\mathrm{GO} / \mathrm{Fe}_{3} \mathrm{O}_{4}$ suspension was deposited onto $\mathrm{Ni}$-foam by vacuum filtration, followed by freezedrying. Finally, the $\mathrm{GO} / \mathrm{Fe}_{3} \mathrm{O}_{4}$ composites were reduced and nitrogendoped simultaneously by hollow cathode (HCD) plasma discharge for 15 min in $\mathrm{Ar}$ and $\mathrm{N}_{2}$ (Figure 1). The as-prepared sample was denoted as $\mathrm{NG} / \mathrm{Fe}_{3} \mathrm{O}_{4}$. A schematic view of the $\mathrm{HCD}$ system used for the plasma treatment and the plasma experiment parameters are shown in Supplementary Fig. S1 and Table SI, respectively.

\section{Hydrothermal synthesis of $\mathrm{RGO} / \mathrm{Fe}_{3} \mathrm{O}_{4}$}

For comparison, $\mathrm{RGO} / \mathrm{Fe}_{3} \mathrm{O}_{4}$ fabricated by the commonly used hydrothermal method was prepared, and the electrochemical behavior was investigated. The $\mathrm{GO} / \mathrm{Fe}_{3} \mathrm{O}_{4}$ suspension was kept in an autoclave at $180{ }^{\circ} \mathrm{C}$ for $12 \mathrm{~h}$, followed by freeze-drying. A paste, including the active materials $\left(\mathrm{RGO} / \mathrm{Fe}_{3} \mathrm{O}_{4}\right)$, conductive carbon black and polyvinylidene fluoride, was used to prepare test electrodes on $\mathrm{Ni}$-foam.

\section{Characterization and electrochemical measurements}

$\mathrm{X}$-ray diffraction (XRD) measurements were performed with $\mathrm{CuKa}$ radiation (D-MAX II A, $\lambda=0.15406 \mathrm{~nm}$ ). A VG ESCALAB MKII (Thermo Scientific, Waltham, MA, USA) was used for the X-ray photoelectron spectroscopy (XPS) investigation. Transmission electron microscopy (TEM) images were acquired by a JEOL2010 (JEOL, Tokyo, Japan). Fourier transform infrared spectroscopy (FTIR) curves were obtained on a VERTEX 70 (Bruker, Ettlingen, Germany). The electrical conductivity of $\mathrm{NG} / \mathrm{Fe}_{3} \mathrm{O}_{4}$ and $\mathrm{RGO} / \mathrm{Fe}_{3} \mathrm{O}_{4}$ aerogel samples was determined via the four-probe method at room temperature. An IVIUMSTAT (Ivium, Eindhoven, Netherlands) electrochemical workstation was used for the electrochemical investigations, and the electrolyte was $6 \mathrm{M} \mathrm{KOH}$. The galvanostatic charge-discharge was measured under different current densities between -1.0 and $0 \mathrm{~V}$. The cyclic voltammetry $(\mathrm{CV})$ was measured at different scan rates $(5,20$, 100 and $200 \mathrm{~V} \mathrm{~s}^{-1}$ ) between -1.0 and $0 \mathrm{~V}$. The electrochemical impedance spectroscopy was acquired from $100 \mathrm{kHz}$ to $0.01 \mathrm{~Hz}$ by applying a signal of $14.14 \mathrm{mV}$.

\section{RESULTS AND DISCUSSION}

Figure 1 shows the experimental procedures of the hydrothermal synthesis of $\mathrm{NG} / \mathrm{Fe}_{3} \mathrm{O}_{4}$. The $\mathrm{GO} / \mathrm{Fe}_{3} \mathrm{O}_{4}$ mixed suspension was

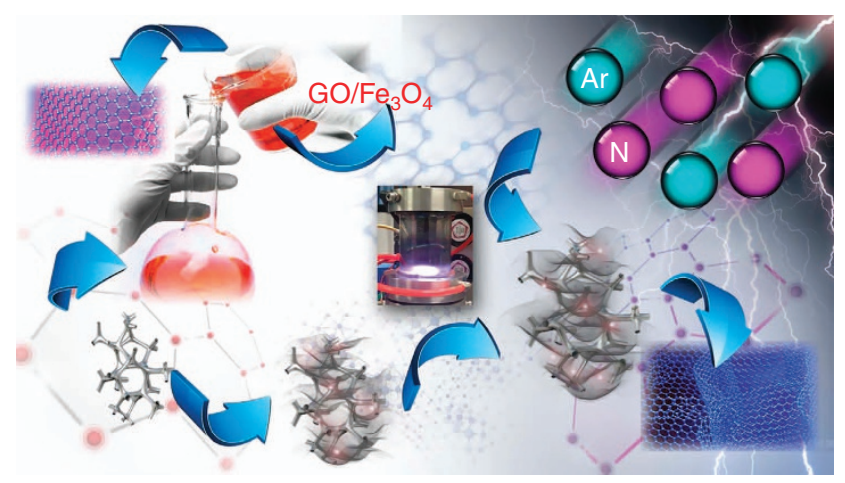

Figure 1 Schematic illustration of the synthetic procedures for $\mathrm{NG} / \mathrm{Fe}_{3} \mathrm{O}_{4}$. deposited onto $\mathrm{Ni}$-foam by vacuum filtration, followed by freeze-drying. Finally, the $\mathrm{GO} / \mathrm{Fe}_{3} \mathrm{O}_{4}$ composites were reduced and nitrogen-doped simultaneously by plasma treatment. Using the hydrothermal method, a gel-like cylinder of $\mathrm{RGO} / \mathrm{Fe}_{3} \mathrm{O}_{4}$ was constructed, as shown in Figure 2a. The formation of a 3D porous network with micrometer-sized pores was confirmed by scanning electron microscopy (SEM), as shown in Figure 2b and 2c. However, as in the commonly used hydrothermal methods, the aggregation of graphene sheets during hydrogel formation was inevitable due to the reduction-induced strong $\pi$-stacking interaction between graphene sheets, which is originally prohibited by the oxygen-containing surface groups of GO. The network walls of $\mathrm{RGO} / \mathrm{Fe}_{3} \mathrm{O}_{4}$ show a tendency of layered aggregation, even though the decoration of $\mathrm{Fe}_{3} \mathrm{O}_{4} \mathrm{NPs}$ as spacers on graphene nanosheets partially prevents the aggregation. Compared with hydrothermally prepared $\mathrm{RGO} / \mathrm{Fe}_{3} \mathrm{O}_{4}, \mathrm{NG} / \mathrm{Fe}_{3} \mathrm{O}_{4}$ exhibits greatly improved $3 \mathrm{D}$ architectures. The SEM image of $\mathrm{NG} / \mathrm{Fe}_{3} \mathrm{O}_{4}$ (Figure 2d) is highly transparent, and the bone of the Ni-foam could be observed clearly. The 3D porous networks are directly formed on the bone by vacuum filtration and freeze-drying. Figure $2 \mathrm{e}$ and $2 \mathrm{f}$ shows that very thin graphene sheets make up the walls of $\mathrm{NG} / \mathrm{Fe}_{3} \mathrm{O}_{4}$. The average size of the pores is several tens of microns, which is larger than that of $\mathrm{RGO} / \mathrm{Fe}_{3} \mathrm{O}_{4}$.

For $\mathrm{RGO} / \mathrm{Fe}_{3} \mathrm{O}_{4}$ nanostructures, a paste including $\mathrm{RGO} / \mathrm{Fe}_{3} \mathrm{O}_{4}$, conductive carbon black and polyvinylidene fluoride was used to prepare test electrodes on $\mathrm{Ni}$-foam. For comparison, a $\mathrm{Ni}$-foam electrode decorated by $\mathrm{RGO} / \mathrm{Fe}_{3} \mathrm{O}_{4}$ was directly prepared by the hydrothermal process without further addition of conductive carbon black and polyvinylidene fluoride, as follows: a Ni-foam electrode was soaked in the $\mathrm{GO} / \mathrm{Fe}_{3} \mathrm{O}_{4}$ suspension and kept in an autoclave at $180^{\circ} \mathrm{C}$ for $12 \mathrm{~h}$, followed by freeze-drying, which resulted in the formation of an $\mathrm{RGO} / \mathrm{Fe}_{3} \mathrm{O}_{4}$-decorated, Ni-foam electrode ( $\mathrm{RGO} / \mathrm{Fe}_{3} \mathrm{O}_{4} @ \mathrm{Ni}$-foam) produced by the hydrothermal process, as shown in Supplementary Fig. S2c. The microstructure of the $\mathrm{RGO} / \mathrm{Fe}_{3} \mathrm{O}_{4} @ \mathrm{Ni}$-foam was similar to that of the $\mathrm{RGO} / \mathrm{Fe}_{3} \mathrm{O}_{4}$, as shown in Figure 2a-2c. In addition, Supplementary Fig. S2d and S2e reveals that the scrolled 3D structures are covered on the $\mathrm{Ni}$ bones and have similar morphology to that of $\mathrm{RGO} / \mathrm{Fe}_{3} \mathrm{O}_{4}$, and the aggregation of graphene sheets during hydrogel formation was observed. This result indicates that the preparation method of the aerogel plays a key role in avoiding the aggregation tendency in the reduction process. The larger pore sizes and thinner pore walls increased the specific surface area of NG/Fe $\mathrm{O}_{4}\left(92 \mathrm{~m}^{2} \mathrm{~g}^{-1}\right)$ compared to that of $\mathrm{RGO} / \mathrm{Fe}_{3} \mathrm{O}_{4}\left(55 \mathrm{~m}^{2} \mathrm{~g}^{-1}\right)$ based on the BET results (Supplementary Fig. S3). These properties of $\mathrm{NG} / \mathrm{Fe}_{3} \mathrm{O}_{4}$ are directly related to the potential applications from adsorbents to supercapacitors.

Both samples had similar TEM images, and the nanosized $\mathrm{Fe}_{3} \mathrm{O}_{4}$ particles were anchored on graphene uniformly, suggesting efficient assembly between the graphene sheets and the NPs (Supplementary Fig. S4 and Figure 2g). In this work, the diameters of the $\mathrm{Fe}_{3} \mathrm{O}_{4}$ particles were in the range of $10-15 \mathrm{~nm}$. The density and size of the $\mathrm{Fe}_{3} \mathrm{O}_{4}$ particles in the $\mathrm{NG} / \mathrm{Fe}_{3} \mathrm{O}_{4}$ and $\mathrm{RGO} / \mathrm{Fe}_{3} \mathrm{O}_{4}$ samples were almost identical. Figure $2 \mathrm{~h}$ shows the XRD curves of $\mathrm{Fe}_{3} \mathrm{O}_{4}, \mathrm{NG} / \mathrm{Fe}_{3} \mathrm{O}_{4}$ and $\mathrm{RGO} / \mathrm{Fe}_{3} \mathrm{O}_{4}$. For all three samples, the main diffraction peaks were assigned to (111), (311), (220), (422), (440), (400) and (511) of the crystal planes of $\mathrm{Fe}_{3} \mathrm{O}_{4}$, consistent with the $\mathrm{Fe}_{3} \mathrm{O}_{4}$ JCPDS card, which suggests that the chemical constitution of $\mathrm{Fe}_{3} \mathrm{O}_{4}$ was retained after the hydrothermal synthesis and plasma treatment. The sharp diffraction peak at $10.3^{\circ}$ in GO, as shown in Supplementary Fig. S5, was replaced by a broad peak between $20^{\circ}$ and $30^{\circ}$, which results from the (002) reflection of the graphene of $\mathrm{NG} / \mathrm{Fe}_{3} \mathrm{O}_{4}$ and $\mathrm{RGO} / \mathrm{Fe}_{3} \mathrm{O}_{4}$, indicating that $\mathrm{GO}$ was reduced by the hydrothermal and plasma treatment. 

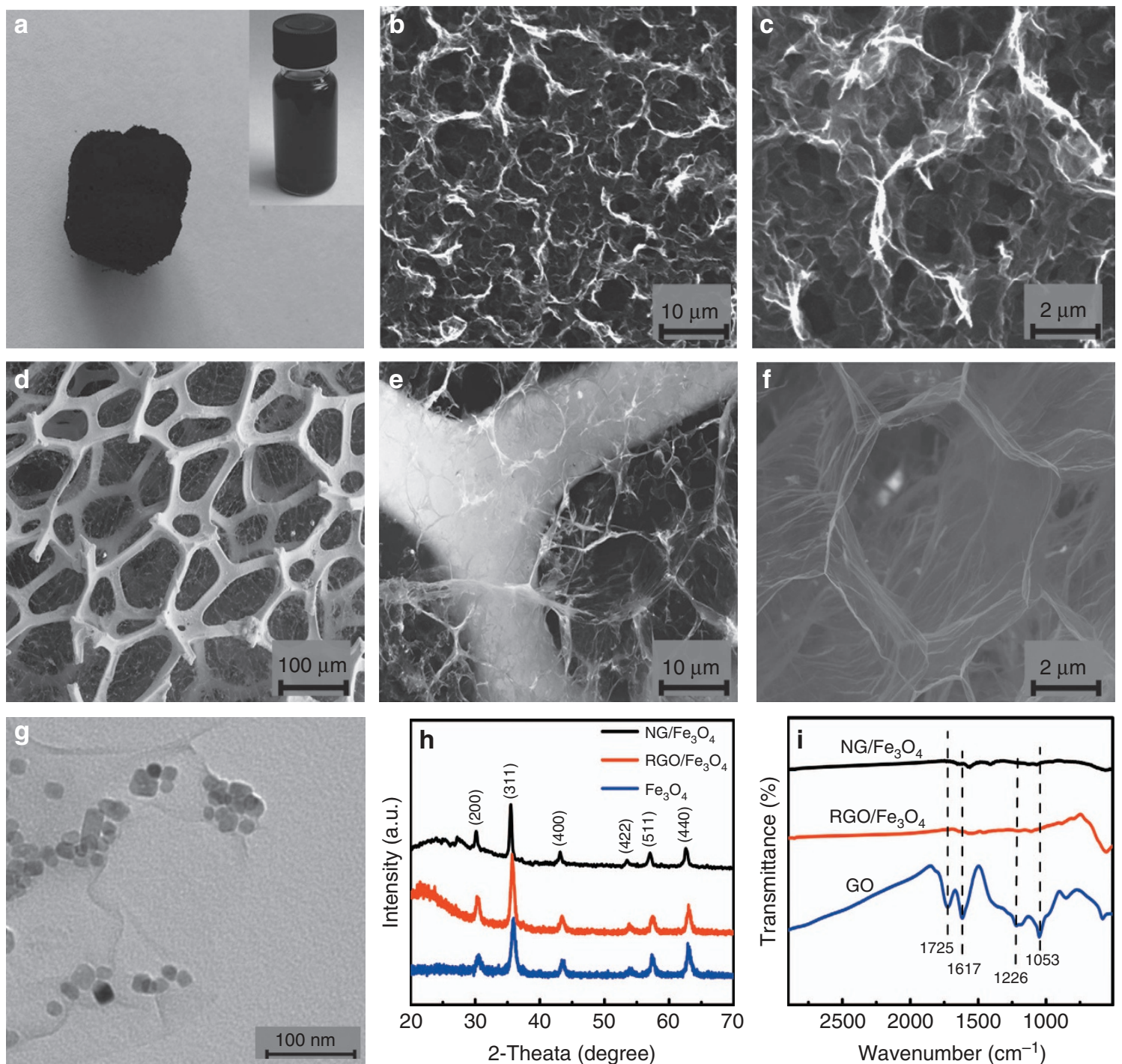

Figure $2 \mathrm{SEM}$ images of $\mathrm{RGO} / \mathrm{Fe}_{3} \mathrm{O}_{4}$ and $\mathrm{NG} / \mathrm{Fe}_{3} \mathrm{O}_{4}$ : (a) photograph of hydrothermal 3D RGO/Fe $3 \mathrm{O}_{4}$; (b, c) SEM images of 3D RGO/Fe $3 \mathrm{O}_{4}$ prepared by the hydrothermal process; (d-f) $\mathrm{SEM}$ images of $3 \mathrm{D} \mathrm{NG} / \mathrm{Fe}_{3} \mathrm{O}_{4}$ with different magnifications. (g) TEM images of $\mathrm{NG} / \mathrm{Fe}_{3} \mathrm{O}_{4}$. (h) XRD picture of the as-prepared $\mathrm{Fe}_{3} \mathrm{O}_{4}, \mathrm{NG} / \mathrm{Fe}_{3} \mathrm{O}_{4}$ and $\mathrm{RGO} / \mathrm{Fe}_{3} \mathrm{O}_{4}$. (i) $\mathrm{FTIR}$ spectra of $\mathrm{GO}, \mathrm{NG} / \mathrm{Fe}_{3} \mathrm{O}_{4}$ and $\mathrm{RGO} / \mathrm{Fe}_{3} \mathrm{O}_{4}$.

Figure $2 \mathrm{i}$ summarizes the FTIR spectra of $\mathrm{GO}, \mathrm{NG} / \mathrm{Fe}_{3} \mathrm{O}_{4}$ and $\mathrm{RGO} / \mathrm{Fe}_{3} \mathrm{O}_{4}$. GO exhibits typical oxygen-related functional groups. The peaks at 1053 and $1226 \mathrm{~cm}^{-1}$ are attributed to the $\mathrm{C}-\mathrm{O}$ and phenolic $\mathrm{C}-\mathrm{OH}$ vibrations, whereas that of $1725 \mathrm{~cm}^{-1}$ is originated from the $\mathrm{C}=\mathrm{O}$ vibration ${ }^{4-46}$. For $\mathrm{RGO} / \mathrm{Fe}_{3} \mathrm{O}_{4}$ and $\mathrm{NG} / \mathrm{Fe}_{3} \mathrm{O}_{4}$, an $\mathrm{Fe}-\mathrm{O}$ related peak at $570 \mathrm{~cm}^{-1}$ was observed ${ }^{47}$, which indicates a $\mathrm{C}-\mathrm{O}-\mathrm{Fe}$ linkage between the graphene nanosheets and the $\mathrm{Fe}_{3} \mathrm{O}_{4}$ NPs.

The XPS surveys of $\mathrm{GO} / \mathrm{Fe}_{3} \mathrm{O}_{4}, \mathrm{RGO} / \mathrm{Fe}_{3} \mathrm{O}_{4}$ and $\mathrm{NG} / \mathrm{Fe}_{3} \mathrm{O}_{4}$ are shown in Figure $3 \mathrm{a}$. For all three samples, peaks corresponding to the $\mathrm{C} 1 \mathrm{~s}$ and $\mathrm{O} 1 \mathrm{~s}$ were observed. Compared with $\mathrm{GO} / \mathrm{Fe}_{3} \mathrm{O}_{4}$, the $\mathrm{O} 1 \mathrm{~s}$ peak intensities of $\mathrm{RGO} / \mathrm{Fe}_{3} \mathrm{O}_{4}$ and $\mathrm{NG} / \mathrm{Fe}_{3} \mathrm{O}_{4}$ decreased, suggesting an increased $\mathrm{C} / \mathrm{O}$ ratio after reduction by the hydrothermal process and plasma treatment, and the oxygen-related functional groups were efficiently removed. This hypothesis was confirmed by the deconvoluted $\mathrm{C} 1 \mathrm{~s}$ spectra (Figure $3 \mathrm{~b}$ ). The weak signals of $\mathrm{C}-\mathrm{O}$ and $\mathrm{C}=\mathrm{O}$ in $\mathrm{RGO} / \mathrm{Fe}_{3} \mathrm{O}_{4}$ compared with that of $\mathrm{GO} / \mathrm{Fe}_{3} \mathrm{O}_{4}$ suggest that most of the $\mathrm{GO}$ was reduced, and the residual oxygen-related functional groups resulted from the incomplete reduction during the hydrothermal process. However, the oxygen-related peaks in the $\mathrm{NG} / \mathrm{Fe}_{3} \mathrm{O}_{4}$ were nearly invisible, which indicates that the plasma treatment was more efficient for the reduction of 3D GO-based hybrids than the hydrothermal method. The formation of $\mathrm{Fe}_{3} \mathrm{O}_{4}$ in $\mathrm{RGO} / \mathrm{Fe}_{3} \mathrm{O}_{4}$ and $\mathrm{NG} / \mathrm{Fe}_{3} \mathrm{O}_{4}$ was further confirmed by the $\mathrm{Fe} 2 \mathrm{p}$ spectra (Figure $3 \mathrm{c}$ ). Two characteristic peaks corresponding to $\mathrm{Fe} 2 \mathrm{p}_{1 / 2}$ and $2 \mathrm{p}_{3 / 2}$ at approximately 724.8 and $711.3 \mathrm{eV}$ were observed, which is consistent with the XRD results. The survey spectra in Figure $3 \mathrm{a}$ indicate the presence of nitrogen in both $\mathrm{RGO} / \mathrm{Fe}_{3} \mathrm{O}_{4}$ and $\mathrm{NG} / \mathrm{Fe}_{3} \mathrm{O}_{4}$. For $\mathrm{RGO} / \mathrm{Fe}_{3} \mathrm{O}_{4}$, the introduction of nitrogen is attributed to the reduction agents used in the hydrothermal process, and the nitrogen in $\mathrm{NG} / \mathrm{Fe}_{3} \mathrm{O}_{4}$ results from $\mathrm{N}_{2}$ plasma treatment. The analysis of the $\mathrm{N}$ chemical bonding is shown in Figure $3 \mathrm{~d}$, and the $\mathrm{N}$ 1s peak can be deconvoluted into three components. The pyridinic and pyrrolic $\mathrm{N}$ at 398.2 and $400.1 \mathrm{eV}$ correspond to the $\mathrm{N}$ atoms of the $\pi$-conjugated system $^{35,48,49}$. The graphitic $\mathrm{N}$ at $401.7 \mathrm{eV}$ corresponds to the $\mathrm{N}$ atoms 

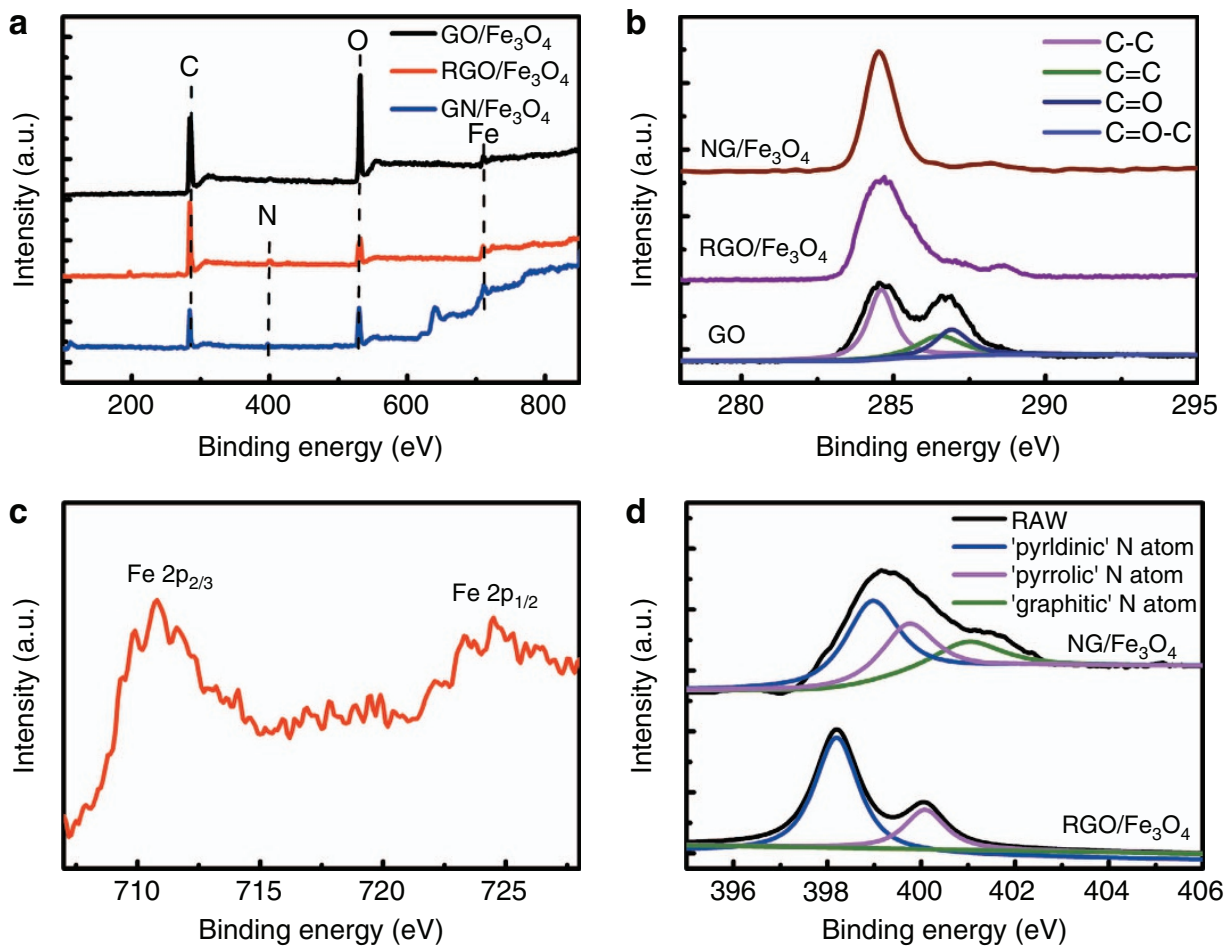

Figure 3 (a) XPS surveys of $\mathrm{GO} / \mathrm{Fe}_{3} \mathrm{O}_{4}, \mathrm{RGO} / \mathrm{Fe}_{3} \mathrm{O}_{4}$ and $\mathrm{NG} / \mathrm{Fe}_{3} \mathrm{O}_{4}$; (b) XPS C 1 s spectrum of the $\mathrm{GO}, \mathrm{RGO} / \mathrm{Fe}_{3} \mathrm{O}_{4}$ and $\mathrm{NG} / \mathrm{Fe}_{3} \mathrm{O}_{4}$ samples; (c) XPS Fe $2 \mathrm{p}$ spectrum of the $\mathrm{NG} / \mathrm{Fe}_{3} \mathrm{O}_{4}$ samples; (d) XPS N 1s spectrum of the $\mathrm{NG} / \mathrm{Fe}_{3} \mathrm{O}_{4}$ and $\mathrm{RGO} / \mathrm{Fe}_{3} \mathrm{O}_{4}$ samples.

replacing the $\mathrm{C}$ atoms inside graphene sheets, which could be observed clearly for $\mathrm{NG} / \mathrm{Fe}_{3} \mathrm{O}_{4}$ but was nearly invisible for $\mathrm{RGO} / \mathrm{Fe}_{3} \mathrm{O}_{4}$, as shown in Figure 3d. The first two types of $\mathrm{N}$ atoms located in the $\pi$ conjugated system account for most of the $\mathrm{N}$ in graphene and contribute one or two p-electrons. The graphitic $\mathrm{N}$ atoms can be considered to be threefold coordinated $\mathrm{sp}^{2} \mathrm{~N}$ in the hexagonal rings of graphene, which plays an important role in regulating the electronic properties of graphene in electrochemical systems ${ }^{48,49}$. According to our results, the graphitic $\mathrm{N}$ doping is difficult to achieve by the hydrothermal method, and plasma treatment is crucial to achieve a high-quality, N-doping, graphene-based aerogel.

A typical three-electrode method was used in this work to investigate the electrochemical behavior. The working electrodes were prepared from $\mathrm{RGO} / \mathrm{Fe}_{3} \mathrm{O}_{4}$ and $\mathrm{NG} / \mathrm{Fe}_{3} \mathrm{O}_{4}$. The CV curves of $\mathrm{RGO} /$ $\mathrm{Fe}_{3} \mathrm{O}_{4}$ and $\mathrm{NG} / \mathrm{Fe}_{3} \mathrm{O}_{4}$ are shown in Figure $4 \mathrm{a}$ and $4 \mathrm{~b}$. The specific capacitances $C\left(\mathrm{~F} \mathrm{~g}^{-1}\right)$ can be calculated from the $\mathrm{CV}$ curves using the following equation ${ }^{44}$ :

$$
C=\left(\int I \mathrm{~d} v\right) /(v m V)
$$

where $V, I, m$ and $v$ are the potential window $(\mathrm{V})$, the current (A), the mass of the active materials $(\mathrm{g})$ and the scan rate $\left(\mathrm{mV} \mathrm{s}^{-1}\right)$, respectively. Figure $4 \mathrm{c}$ summarizes the specific capacitance of the two samples as a function of the scan rate. The $\mathrm{NG} / \mathrm{Fe}_{3} \mathrm{O}_{4}$ electrode reached a maximum of $386 \mathrm{~F} \mathrm{~g}^{-1}$ at $5 \mathrm{mV} \mathrm{s}^{-1}$, which was much higher than that of the $\mathrm{RGO} / \mathrm{Fe}_{3} \mathrm{O}_{4}$ electrode $\left(253.3 \mathrm{~F} \mathrm{~g}^{-1}\right)$. Due to the in situ preparation of the $\mathrm{RGO} / \mathrm{Fe}_{3} \mathrm{O}_{4} @ \mathrm{Ni}$-foam electrode, the specific capacitance at $5 \mathrm{mV} \mathrm{s}^{-1}$ was $267 \mathrm{~F} \mathrm{~g}^{-1}$, which was slightly improved compared with that of the $\mathrm{RGO} / \mathrm{Fe}_{3} \mathrm{O}_{4}$ electrode but was still far behind the $\mathrm{NG} / \mathrm{Fe}_{3} \mathrm{O}_{4}$ electrode. The galvanostatic charge - discharge lines of the $\mathrm{NG} / \mathrm{Fe}_{3} \mathrm{O}_{4}$ electrode exhibit an almost symmetric triangular shape (Figure $4 \mathrm{~d}$ ), indicating a high reversibility in the charge and discharge cycle ${ }^{50-52}$. Figure $5 \mathrm{a}$ shows the Nyquist plots of the $\mathrm{NG} / \mathrm{Fe}_{3} \mathrm{O}_{4}$ and $\mathrm{RGO} / \mathrm{Fe}_{3} \mathrm{O}_{4}$ electrodes. For both samples, the Nyquist plots consist of two distinct parts: a linear part at low frequency and a semicircle part at high frequency. The two samples exhibit similar plots. In the high-frequency part (inset of Figure 5a), the charge transfer resistance (Rct) was calculated as 0.9 and $0.85 \Omega$ for the $\mathrm{NG} / \mathrm{Fe}_{3} \mathrm{O}_{4}$ and $\mathrm{RGO} / \mathrm{Fe}_{3} \mathrm{O}_{4}$ electrodes, respectively. The bulk electrical conductivity of the $\mathrm{NG} / \mathrm{Fe}_{3} \mathrm{O}_{4}$ aerogel sample was 174 $\mathrm{S} \mathrm{m}^{-1}$, three times greater than that of $\mathrm{RGO} / \mathrm{Fe}_{3} \mathrm{O}_{4}\left(55 \mathrm{~S} \mathrm{~m}^{-1}\right)$. Although the conductive agent (conductive carbon black in this work) was absent in the preparation progress of the $\mathrm{NG} / \mathrm{Fe}_{3} \mathrm{O}_{4}$ electrode, the Rct of the $\mathrm{NG} / \mathrm{Fe}_{3} \mathrm{O}_{4}$ electrode has a similar value to that of the $\mathrm{RGO} / \mathrm{Fe}_{3} \mathrm{O}_{4}$ electrode, which is also lower than in some previous studies ${ }^{44,53}$, indicating the excellent conductivity of $\mathrm{NG} / \mathrm{Fe}_{3} \mathrm{O}_{4}$. The $\mathrm{NG} / \mathrm{Fe}_{3} \mathrm{O}_{4}$ electrode shows excellent cycling stability, as shown in Figure 5b, and there is no obvious decrease in capacitance after 1000 cycles, which is crucial for commercial applications of supercapacitors $^{54-56}$.

The addition of pseudocapacitor materials is an efficient way to improve the performance of graphene-based supercapacitors. Two very important pseudocapacitor materials are transition metal compounds and conducting polymers. Generally, supercapacitors based on conducting polymers have higher specific capacitance than transition metal compounds; however, their cyclic stability is often poor ${ }^{57}$. Transition metal compounds have improved cyclic stability, but the weaknesses of the transition metal compounds are poor mechanical strength and low electrical conductivity. An efficient strategy to improve supercapacitor performance would be a combination of 

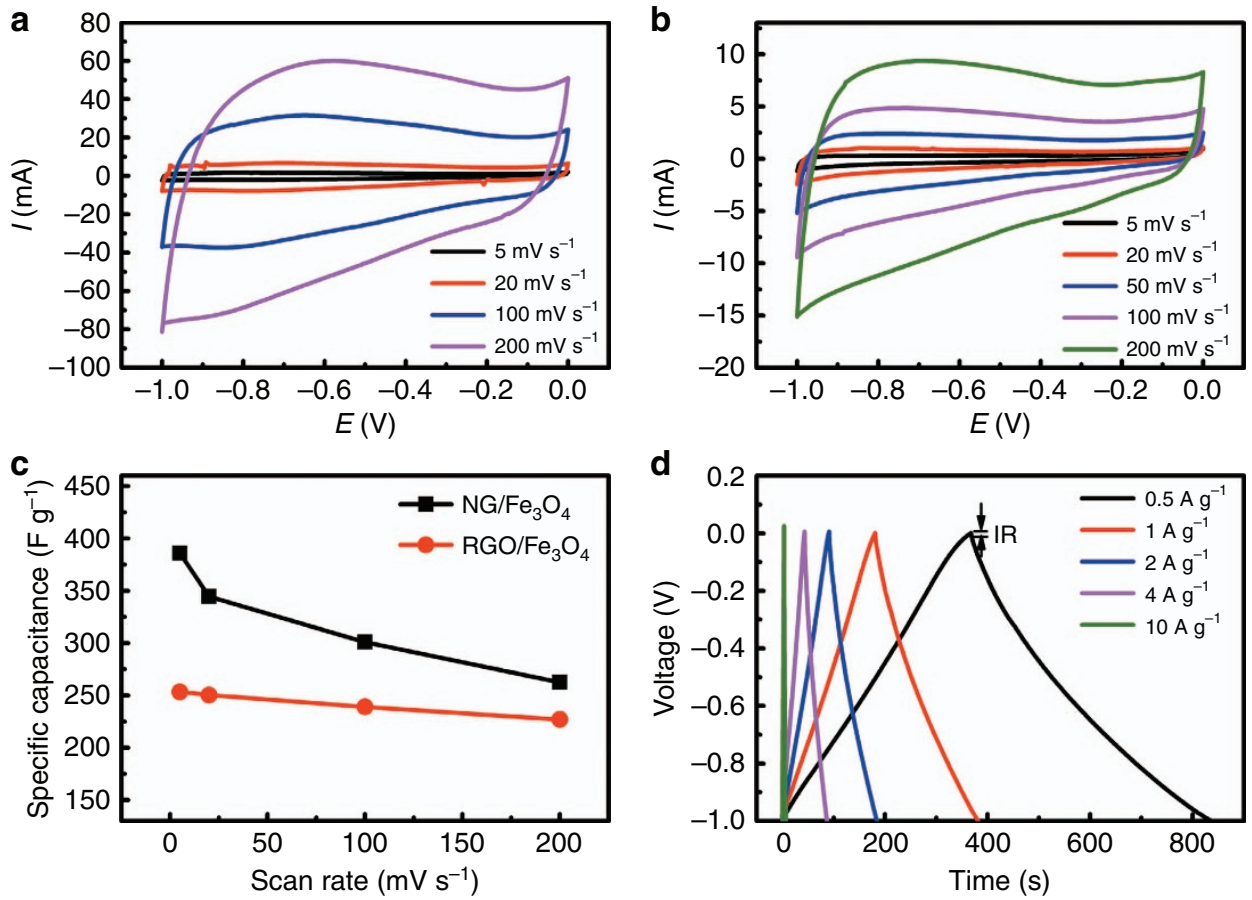

Figure 4 (a) $\mathrm{CV}$ curves of the $\mathrm{RGO} / \mathrm{Fe}_{3} \mathrm{O}_{4}$ electrode. (b) $\mathrm{CV}$ curves of the $\mathrm{NG} / \mathrm{Fe}_{3} \mathrm{O}_{4}$ electrode. (c) Variation of the specific capacitance against the scan rate for the $\mathrm{RGO} / \mathrm{Fe}_{3} \mathrm{O}_{4}$ and $\mathrm{NG} / \mathrm{Fe}_{3} \mathrm{O}_{4}$ electrodes. (d) Galvanostatic charge - discharge curves of the $\mathrm{NG} / \mathrm{Fe}_{3} \mathrm{O}_{4}$ electrode.
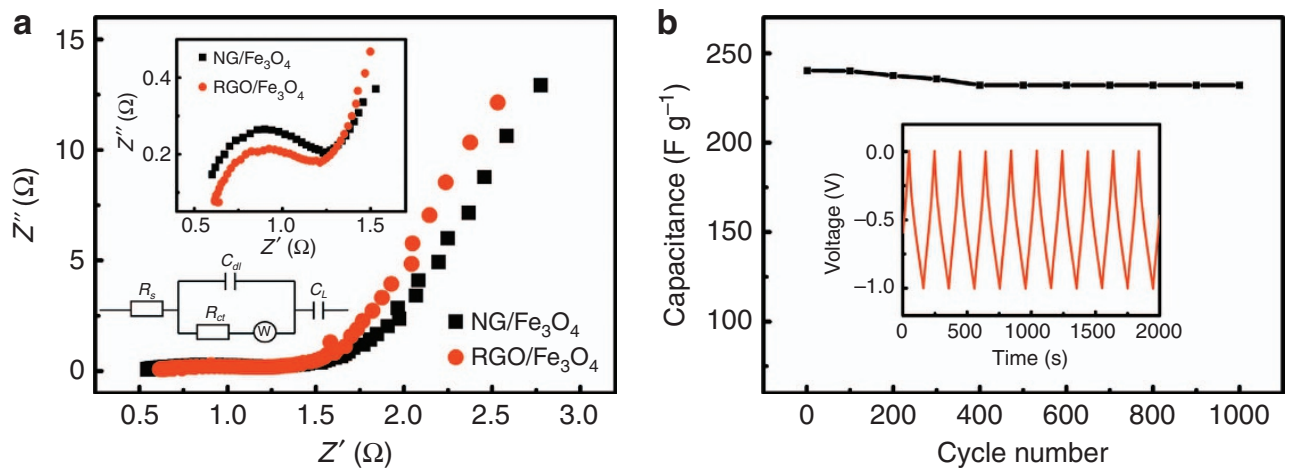

Figure 5 (a) EIS of the $\mathrm{RGO} / \mathrm{Fe}_{3} \mathrm{O}_{4}$ and $\mathrm{NG} / \mathrm{Fe}_{3} \mathrm{O}_{4}$ electrodes, with insets showing the high-frequency parts and the equivalent circuit diagram used for fitting the EIS date. (b) Cycle performance of the $\mathrm{NG} / \mathrm{Fe}_{3} \mathrm{O}_{4}$ electrode at a current density of $2 \mathrm{~A} \mathrm{~g} \mathrm{~g}^{-1}$. The inset shows the first 10 cycles of galvanostatic charge-discharge. EIS, electrochemical impedance spectra.

transition metal compounds in highly conductive 3D graphene frameworks. In the present work, we further developed the commonly used hydrothermal method and have shown that plasma-treated $\mathrm{NG} / \mathrm{Fe}_{3} \mathrm{O}_{4}$ would greatly enhance supercapacitor performance. Due to the non-toxicity, easy redox reactions and low cost of $\mathrm{Fe}_{3} \mathrm{O}_{4}$, it has become a good candidate as a pseudocapacitor material, although its theoretical specific capacitance is lower than that of some other transition metal compounds, such as $\mathrm{MnO}_{2}, \mathrm{RuO}_{2}$ and $\mathrm{V}_{2} \mathrm{O}_{5}{ }^{20,58-60}$. Table 1 summarizes the performances of supercapacitors prepared with similar 3D systems ${ }^{20,58,59,61-67}$. For 3D graphene aerogels prepared by CVD with $\mathrm{Ni}$-foam and integrated with oxides ${ }^{58,59,67}$, they exhibit large specific surface area and low defects, and these aerogels can be used directly without further reduction. However, the
CVD methods generally require rigorous conditions, such as high temperature, templates and dangerous gas. Furthermore, the limited output prevents its expansion for industrialization. In the present work, 3D structures were prepared by in situ plasma reduction, which is a simple and feasible strategy that can be expanded for large-scale production of nitrogen-doped, graphene-based aerogel, and various active nanomaterials can be incorporated into the $3 \mathrm{D}$ hybrid structures. In addition, the present method demonstrates competitive specific capacitance compared with CVD methods.

Compared with other supercapacitors based on $\mathrm{Fe}_{3} \mathrm{O}_{4} / \mathrm{RGO}$ structures ${ }^{61-64}$, the present $\mathrm{NG} / \mathrm{Fe}_{3} \mathrm{O}_{4}$ shows excellent specific capacitance and charge transfer ability. Because of the intrinsic properties of the materials, the specific capacitance of the $\mathrm{NG} / \mathrm{Fe}_{3} \mathrm{O}_{4}$ electrode is 
Table 1 Summary of the capacitive performance of the supercapacitors based on similar structures

\begin{tabular}{|c|c|c|c|c|c|c|}
\hline Sample & Fabrication method & Cs $\left(\mathrm{F} \mathrm{g}^{-1}\right)$ & $R(\Omega)$ & $T$ & $c(\%)$ & Ref \\
\hline $\mathrm{MnO}_{2} / \mathrm{RGO}$ & Dip coating & 450 & 6.5 & 10000 & 90 & 20 \\
\hline $\mathrm{RuO}_{2} / \mathrm{CNT} / \mathrm{GE} / \mathrm{Ni}$-foam & CVD/dip coating & 502.7 & 1.02 & 8000 & 106 & 59 \\
\hline $\mathrm{Fe}_{3} \mathrm{O}_{4} / \mathrm{G}$ & 2D sandwich-like sheet grown on GO/RGO & 349 & - & 1000 & - & 61 \\
\hline $\mathrm{Fe}_{3} \mathrm{O}_{4} / \mathrm{RGO}$ & Hydrogen reducing & 262 & - & 1000 & - & 62 \\
\hline RGO/porous & Electrochemical exfoliation & 325 & 3.6 & 5000 & 98 & 65 \\
\hline 3D-RGO & Hydrothermal polymerization/carbonization & 225 & - & 5000 & 94 & 66 \\
\hline GE/Ni-foam & CVD & 180 & 0.93 & 2000 & 100 & 67 \\
\hline
\end{tabular}

Abbreviations: $C$, retention rate of $C_{\mathrm{S}}$ after the cycle life test; $C_{\mathrm{S}}$, specific capacitance; CNT, carbon nanotube; GE, graphene; GS, graphene sheet; $R$, internal resistance obtained from the electrochemical impedance spectra measurements; $T$, cycles of the cycle life test.

still lower than that of $\mathrm{MnO}_{2} / \mathrm{RGO}$ and $\mathrm{RuO}_{2} / \mathrm{RGO}$ electrodes $20,58,59$. However, the present method is a simple and feasible one compared with the traditional hydrothermal process and CVD method. The active nanomaterials can be further expanded for other compounds of transition metals, such as $\mathrm{Co}, \mathrm{Ni}, \mathrm{Mn}, \mathrm{Mo}$ and $\mathrm{V}$. The dip-coating and plasma treatment strategy works well for the $3 \mathrm{D} \mathrm{NG} / \mathrm{Fe}_{3} \mathrm{O}_{4}$ system and would also be effective for other compounds of transition metals. The properties of some other materials, such as cobalt oxide and $\mathrm{Ni}(\mathrm{OH})_{2}$, which have 'battery' electrochemical behavior, are not compared ${ }^{68}$.

\section{CONCLUSIONS}

In conclusion, we have developed a plasma treatment approach to fabricate $3 \mathrm{D} \mathrm{NG} / \mathrm{Fe}_{3} \mathrm{O}_{4}$ nanostructures as high-performance supercapacitor electrode materials. During the plasma process, the GO of the $\mathrm{GO} / \mathrm{Fe}_{3} \mathrm{O}_{4}$ materials was reduced and $\mathrm{N}$-doped. The as-prepared $\mathrm{NG} / \mathrm{Fe}_{3} \mathrm{O}_{4}$ electrode exhibited good electrochemical performance, especially high specific capacitance, excellent stability and low charge transfer resistance. As a mature, simple, efficient, low-cost and environmentally friendly method, plasma treatment is a promising process for the preparation and modification of energy storage materials.

\section{ACKNOWLEDGEMENTS}

The authors are grateful for funding by the National Natural Science Foundation of China (grant nos. 61322406, 61376020, 11474035 and 61574021).

1 Chen ZP, Ren WC, Gao LB, Liu BL, Pei SF et al. Three-dimensional flexible and conductive interconnected graphene networks grown by chemical vapour deposition. Nat Mater 2011; 10: 424-428.

2 Niu ZQ, Chen J, Hng HH, Ma J, Chen XD. A leavening strategy to prepare reduced graphene oxide foams. Adv Mater 2012; 24: 4144-4150.

3 Dai ZG, Xiao XH, Wu Wei, Zhang YP, Liao L et al. Plasmon-driven reaction controlled by the number of graphene layers and localized surface plasmon distribution during optical excitation. Light Sci App/ 2015; 4: e342, doi:10.1038/Isa.2015.115.

4 Meng C, Yu SL, Wang HQ, Cao Y, Tong LM et al. Graphene-doped polymer nanofibers for low-threshold nonlinear optical waveguiding. Light Sci Appl 2015; 4: e348, doi:10.1038/lsa.2015.121.

5 Chen JH, Zheng BC, Shao GH, Ge SJ, Xu F et al. An all-optical modulator based on a stereo graphene-microfiber structure. Light Sci Appl 2015; 4: e360, doi:10.1038/Isa.2015.133.

6 Xu YX, Sheng KX, Li C, Shi GQ. Self-assembled graphene hydrogel via a one-step hydrothermal process. ACS Nano 2010; 4: 4324-4330.

7 Yin SY, Zhang YY, Kong JH, Zou CJ, Li CM et al. Assembly of graphene sheets into hierarchical structures for high-performance energy storage. ACS Nano 2011; 5: 3831-3838.

8 Liu F, Seo TS. A controllable self-assembly method for large-scale synthesis of graphene sponges and free-standing graphene films. Adv Funct Mater 2010; 20: 1930-1936.
9 Maiti UN, Lim J, Lee KE, Lee WJ, Kim So. Three-dimensional shape engineered interfacial gelation of reduced graphene oxide for high rate large capacity supercapacitors. Adv Mater 2014; 26: 615-619.

$10 \mathrm{Xu} Y X$, Lin $Z Y$, Huang $X Q$, Wang $Y$, Huang $Y$ et al. Functionalized graphene hydrogelbased high-performance supercapacitors. Adv Mater 2013; 25: 5779-5784.

11 Ariga K, Vinu A, Yamauchi Y, Ji QM, Hill JP. Nanoarchitectonics for mesoporous materials. Bull Chem Soc Jpn 2012; 85: 1-32.

12 Li ZX, Barnes JC, Bosoy A, Stoddart JF, Zink JI. Mesoporous silica nanoparticles in biomedical applications. Chem Soc Rev 2012; 41: 2590-2605.

13 Tang FQ, Li LL, Chen D. Mesoporous silica nanoparticles: synthesis, biocompatibility and drug delivery. Adv Mater 2012; 24: 1504-1534.

14 Worsley MA, Pauzauskie PJ, Olson TY, Biener J, Satcher JH et al. Synthesis of graphene aerogel with high electrical conductivity. J Am Chem Soc 2010; 132: 14067-14069.

15 Luo JY, Jang HD, Sun T, Xiao L, He Z et al. Compression and aggregation-resistant particles of crumpled soft sheets. ACS Nano 2011; 5: 8943-8949.

16 Ji QM, Honma I, Paek SM, Akada M, Hill JP et al. Layer-by-layer films of graphene and ionic liquids for highly selective gas sensing. Angew Chem Int Ed 2010; 49: 9737-9739.

17 El-Kady MF, Strong V, Dubin S, Kaner RB. Laser scribing of high-performance and flexible graphene-based electrochemical capacitors. Science 2012; 335: 1326-1330.

18 Wei W, Yang SB, Zhou HX, Lieberwirth I, Feng XL et al. 3D graphene foams cross-linked with pre-encapsulated $\mathrm{Fe}_{3} \mathrm{O}_{4}$ nanospheres for enhanced lithium storage. Adv Mater 2013; 25: 2909-2914.

19 Li C, Shi GQ. Three-dimensional grapheme architectures. Nanoscale 2012; 4: 5549-5563.

$20 \mathrm{Ge} \mathrm{J}, \mathrm{Yao} \mathrm{HB}, \mathrm{Hu}$ W, Yu XF, Yan YX et al. Facile dip coating processed graphene/ $\mathrm{MnO}_{2}$ nanostructured sponges as high performance supercapacitor electrodes. Nano Energy 2013; 2: 505-513.

21 Huang KJ, Wang L, Zhang JZ, Wang LL, Mo YP. One-step preparation of layered molybdenum disulfide/multi-walled carbon nanotube composites for enhanced performance supercapacitor. Energy 2014; 67: 234-240.

22 Augustyn V, Simonbc P, Dunn B. Pseudocapacitive oxide materials for high-rate electrochemical energy storage. Energy Environ Sci 2014; 7: 1597-1614.

23 Shi EZ, Li HB, Xu WJ, Wu ST, Wei JQ et al. Improvement of graphene-Si solar cells by embroidering graphene with a carbon nanotube spider-web. Nano Energy 2015; 17: 216-223.

24 Wu SP, Ge RY, Lu MJ, Xu R, Zhang Z. Graphene-based nano-materials for lithium-sulfur battery and sodium-ion battery. Nano Energy 2015; 15: 379-405.

25 Fan ZJ, Yan J, Zhi LJ, Zhang Q, Wei T et al. A three-dimensional carbon nanotube/ graphene sandwich and its application as electrode in supercapacitors. Adv Mater 2010; 22: 3723-3728.

26 Estevez L, Kelarakis A, Gong QM, Da'as EH, Giannelis EP. Multifunctional graphene/platinum/nafion hybrids via ice templating. J Am Chem Soc 2011; 133: 6122-6125.

27 Vickery JL, Patil AJ, Mann S. Fabrication of graphene-polymer nanocomposites with higher-order three-dimensional architectures. Adv Mater 2009; 21: 2180-2184.

28 Du J, Lai XY, Yang NL, Zhai J, Kisailus D et al. Hierarchically ordered macromesoporous $\mathrm{TiO}_{2}$-graphene composite films: improved mass transfer, reduced charge recombination, and their enhanced photocatalytic activities. ACS Nano 2011; 5: 590-596.

29 Cong HP, Ren XC, Wang P, Yu SH. Macroscopic multifunctional graphene-based hydrogels and aerogels by a metal ion induced self-assembly process. ACS Nano 2012; 6: 2693-2703.

30 Tang ZH, Shen SL, Zhuang J, Wang X. Noble-metal-promoted three-dimensional macroassembly of single-layered graphene oxide. Angew Chem Int Ed 2010; 49: 4603-4607.

31 Wang $\mathrm{Y}$, Wu YP, Huang Y, Zhang F, Yang $X$ et al. Preventing graphene sheets from restacking for high-capacitance performance. J Phys Chem C 2011; 115: 23192-23197. 
32 Bai H, Sheng KX, Zhang PF, Li C, Shi GQ. Graphene oxide/conducting polymer composite hydrogels. J Mater Chem 2011; 21: 18653-18658.

33 Xu YX, Wu QO, Sun YQ, Bai H, Shi GQ. Three-dimensional self-assembly of graphene oxide and DNA into multifunctional hydrogels. ACS Nano 2010; 4: 7358-7362.

34 Chen WF, Li SR, Chen CH, Yan LF. Self-assembly and embedding of nanoparticles by in situ reduced graphene for preparation of a 3D graphene/nanoparticle aerogel. Adv Mater 2011; 23: 5679-5683.

35 Wei DC, Liu YQ, Wang Y, Zhang HL, Huang LP et al. Synthesis of N-doped graphene by chemical vapor deposition and its electrical properties. Nano Lett 2009; 9: 1752-1758

36 Giovannetti G, Khomyakov PA, Brocks G, Karpan VM, Brink JV et al. Doping graphene with metal contact. Phys Rev Lett 2008; 101: 026803.

37 Wang Y, Shao YY, Matson DW, Li JH, Lin YH. Nitrogen-doped graphene and its application in electrochemical biosensing. ACS Nano 2010; 4: 1790-1798.

38 Zhou YC, Leng YH, Zhou WJ, Huang JL, Zhao MW et al. Sulfur and nitrogen self-doped carbon nanosheets derived from peanut root nodules as high-efficiency non-metal electrocatalyst for hydrogen evolution reaction. Nano Energy 2015; 16: 357-366.

39 Chai LY, Wang JX, Wang HY, Zhang LY, Yu WT et al. Porous carbonized grapheneembedded fungus film as an interlayer for superior Li-S batteries. Nano Energy 2015, 17: 224-232.

40 Wang XR, Li XL, Zhang L, Yoon Y, Weber PK et al. N-Doping of graphene through electrothermal reactions with ammonia. Science 2009; 324: 768-771.

41 Panchokarla LS, Subrahmanyam KS, Saha SK, Govindaraj A, Krishnamurthy HR et al. Synthesis, structure, and properties of boron- and nitrogen-doped graphene. Adv Mater 2009; 21: 4726-4730.

42 Qin Y, Yuan J, Li J, Chen DC, Kong Y et al. Crosslinking graphene oxide into robust 3D porous N-doped graphene. Adv Mater 2015; 27: 5171-5175.

43 Lin YC, Lin CY, Chiu PW. Controllable graphene N-doping with ammonia plasma. Appl Phys Lett 2010; 96: 133110.

$44 \mathrm{Wu}$ XL, Wen T, Guo HL, Yang SB, Wang XK et al. Biomass-derived sponge-like carbonaceous hydrogels and aerogels for supercapacitors. ACS Nano 2013; 7: 3589-3597.

45 Sun XM, Li YD. Colloidal carbon spheres and their core/shell structures with noble-meta nanoparticles. Angew Chem Int Ed 2004; 43: 597-601.

46 Grzyb B, Hildenbrand C, Berthon-Fabry S, Bégin D, Job N et al. Functionalisation and chemical characterisation of cellulose-derived carbon aerogels. Carbon 2010; 48: 2297-2307.

47 Wang G, Liu T, Xie XL, Ren ZY, Bai JB et al. Structure and electrochemical performance of $\mathrm{Fe}_{3} \mathrm{O}_{4}$ /graphene nanocomposite as anode material for lithium-ion batteries. Mater Chem Phys 2011; 128: 336-340.

48 Wang XB, Liu YQ, Zhu DB, Zhang L, Ma HZ et al. Controllable growth, structure and low field emission of well-aligned $\mathrm{CN}_{\mathrm{x}}$ nanotubes. J Phys Chem B 2002; 106: 2186-2190.

49 Casanovas J, Ricart JM, Rubio J, Illas F, Jiménez-Mateos JM. Origin of the large N 1s binding energy in $\mathrm{X}$-ray photoelectron spectra of calcined carbonaceous materials. J Am Chem Soc 1996; 118: 8071-8076.

50 Wang HB, Liu ZH, Chen X, Han PX, Dong SM et al. Exfoliated graphite nanosheets/ carbon nanotubes hybrid materials for superior performance supercapacitors. J Solid State Electrochem 2011; 15: 1179-1184.

51 Lei ZB, Shi FH, Lu L. Incorporation of $\mathrm{MnO}_{2}$-coated carbon nanotubes between graphene sheets as supercapacitor electrode. ACS App/ Mater Interfaces 2012; 4: 1058-1064.

52 Choi BG, Yang MH, Hong WH, Choi JW, Huh YS. 3D macroporous graphene frameworks for supercapacitors with high energy and power densities. ACS Nano 2012; 6: 4020-4028.
53 Qie L, Chen WM, Xu HH, Xiong XQ, Jiang $Y$ et al. Synthesis of functionalized 3D hierarchical porous carbon for high-performance supercapacitors. Energy Environ Sci 2013; 6: 2497-2504

54 Sun WP, Rui XH, Ulaganathan M, Madhavi S, Yan QY. Few-layered $\mathrm{Ni}(\mathrm{OH})_{2}$ nanosheets for high-performance supercapacitors. J Power Sources 2015; 295: 323-328.

$55 \mathrm{He}$ SJ, Chen W. Application of biomass-derived flexible carbon cloth coated with $\mathrm{MnO}_{2}$ nanosheets in supercapacitors. J Power Sources 2015; 294: 150-158.

56 Lin SY, Zhang XT. Two-dimensional titanium carbide electrode with large mass loading for supercapacitor. J Power Sources 2015; 294: 354-359.

57 He SJ, Chen W. 3D graphene nanomaterials for binder-free supercapacitors: scientific design for enhanced performance. Nanoscale 2015; 7: 6957-6990.

58 Zhu GY, He Z, Chen J, Zhao J, Feng XM et al. Highly conductive three-dimensional $\mathrm{MnO}_{2}$-carbon nanotube-graphene-Ni hybrid foam as a binder-free supercapacitor electrode. Nanoscale 2014; 6: 1079-1085.

59 Wang W, Guo SR, Lee I, Ahmed K, Zhong JB et al. Hydrous ruthenium oxide nanoparticles anchored to graphene and carbon nanotube hybrid foam for supercapacitors. Sci Rep 2014; 4: 4452-4460.

60 Shakir I, Ali Z, Bae J, Park J, Kang DJ. Layer by layer assembly of ultrathin $\mathrm{V}_{2} \mathrm{O}_{5}$ anchored MWCNTs and graphene on textile fabrics for fabrication of high energy density flexible supercapacitor electrodes. Nanoscale 2014; 6: 4125-4130.

$61 \mathrm{Qu}$ QT, Yang SB, Feng XL. 2D sandwich-like sheets of iron oxide grown on graphene as high energy anode material for supercapacitors. Adv Mater 2011; 23: 5574-5580.

62 Cheng JP, Shou QL, Wu JS, Liu F, Dravid VP et al. Influence of component content on the capacitance of magnetite/reduced graphene oxide composite. J Electroanal Chem 2013; 698: 1-8.

63 Wang QH, Jiao LF, Du HM, Wang YJ, Yuan HT. $\mathrm{Fe}_{3} \mathrm{O}_{4}$ nanoparticles grown on graphene as advanced electrode materials for supercapacitors. J Power Sources 2014; 245: 101-106.

$64 \mathrm{Liu} \mathrm{MM}$, Sun J. In situ growth of monodisperse $\mathrm{Fe}_{3} \mathrm{O}_{4}$ nanoparticles on graphene as flexible paper for supercapacitor. J Mater Chem A 2014; 2: 12068-12074.

65 Jung SM, Mafra DL, Lin CT, Jung HY, Kong J. Controlled porous structures of graphene aerogels and their effect on supercapacitor performance. Nanoscale 2015; 7 4386-4393.

66 Zhang L, Zhang F, Yang X, Long GK, Wu YP et al. Porous 3D graphene-based bulk materials with exceptional high surface area and excellent conductivity for supercapacitors. Sci Rep 2013; 3: 10481-10489.

67 Bo Z, Zhu WG, Ma W, Wen ZH, Shuai XR et al. Graphene supercapacitors: vertically oriented graphene bridging active-layer/current-collector interface for ultrahigh rate supercapacitors. Adv Mater 2013; 25: 5798-5806.

68 Thierry B, Daniel B, Jeffrey WL. To be or not to be pseudocapacitive. J Electrochem Soc 2015; 162: A5185-A5189.

(c) (i) This work is licensed under a Creative Commons Attribution 4.0 International License. The images or other third party material in this article are included in the article's Creative Commons license, unless indicated otherwise in the credit line; if the material is not included under the Creative Commons license, users will need to obtain permission from the license holder to reproduce the material. To view a copy of this license, visit http://creativecommons.org/licenses/by/4.0/

C The Author(s) 2016

Supplementary Information for this article can be found on the Light: Science \& Applications' website (http://www.nature.com/lsa). 